\title{
GROUNDWATER FORMATION BELOW CHERNOZEM SOILS - EFFECT OF MINERAL FERTILIZATION, RAINY AND DRY PERIODS
}

\author{
FORMOWANIE WÓD GRUNTOWYCH PONIŻEJ WARSTWY GLEB \\ CZARNOZIEMU - WPLYW NAWOŻENIA MINERALNEGO \\ ORAZ OKRESÓW DESZCZOWYCH I SUCHYCH
}

\begin{abstract}
Chernozem soil samples from the east of Austria have been packed into columns in order to investigate the effects of mineral fertilization on the composition of water, released to deeper layers. A solution imitating NPK fertilization was added on top of water-saturated columns, and washed down with $150 \mathrm{~cm}^{3}$ portions (about 0.1 pore volumes) every day except weekends, for 2 months. The eluates were collected and analyzed by ICP and AAS methods. After about one pore volume, a strong peak in alkali, alkaline earths, and sulfate occurred in the eluates, due to ion exchange with the fertilizer solution. After this, most concentrations in the eluates approached a steady state again, but lower than the levels met before. After a period of drying, the release of $\mathrm{K}$ and $\mathrm{S}$, as well as $\mathrm{P}$ in 2 of 3 cases, increased, whereas the release of Fe and $\mathrm{Mn}$ decreased. Before the eluates entered the sample collection vessels, ochre precipitation scavenged many solutes $(\mathrm{Cr}>\mathrm{Al}>\mathrm{Pb}>\mathrm{P}>\mathrm{V}>\mathrm{Fe})$, but left Mo-Sr-Mg-K-Se-B rather untouched.
\end{abstract}

Keywords: soil columns, vertical migration, ochre formation, fertilization, subsurface groundwater

In plain areas of intense agriculture, the composition of newly formed ground water is greatly influenced by the vertical mobility of solutes mobilized by rainy events. Apart from the washout of the atmosphere, water-soluble soil fractions get released into deeper layers, in particular through bare soil after harvest and before seed germination [1], when there are no plant roots ready for resorption. Fertilizers contain large amounts of readily soluble substances, to ensure high availability to crops. Parts of readily dissolved amounts are resorbed resp. exchanged in deeper soil layers and do not reach groundwater levels. Because groundwater might be used for human consumption later on (drinking, washing etc.), it might be interesting to consider possible changes of water hardness, soluble iron and other characteristics of practical interest. In order to keep all added nutrients available to his crops, the farmer should be concerned to avoid losses of his fertilizer to the groundwater. A second change of composition occurs when the newly formed ground water is aerated

\footnotetext{
${ }^{1}$ Austrian Agency for Health and Food Safety, Spargelfeldstrasse 191, A - 1220 Vienna, Austria, phone 004350555 32801, email: manfred.sager@ages.at
} 
again, because of ochre formation and co-precipitation reactions within the well. Ochres from mine drainage waters formed under strongly acid conditions contained mainly high $\mathrm{Al}$, whereas ochres formed under slightly acid or neutral conditions, were enriched in $\mathrm{Cu}, \mathrm{Pb}$, $\mathrm{Zn}, \mathrm{Mn}$, and As [2].

In Austria, $30 \%$ of wet precipitation may contribute to groundwater formation on the average, but large variations due to different climatic conditions occur. In Austria, groundwater has to be kept clean by law in general, irrespective of use [3].

The compositions of percolation water in the non-saturated soil layers and in the corresponding groundwater are usually not fundamentally different. When rain water enters the non-saturated region of soil, many reactions can take place, like dissolution and dilution, filtration, adsorption - desorption, ion exchange, oxidation, reduction, precipitation hydrolysis, complexation, as well as accumulation, destruction and transformation by biota $[4,5]$.

Column studies are frequently used to simulate transport phenomena of nutrients, trace metals, radioactive substances and pesticides, as well as the hydrological regime per se [6-9]. They are much more laborious and expensive than batch extraction methods, but they consider also microbial life and long-term effects. Whereas in batch extraction, a quasi-equilibrium between the respective solid and an excess of water is obtained, column experiments yield a lot of eluate fractions versus time ( $\mathrm{eg}$ for the entire vegetation period), and also concentration profile of constituents bound to the remaining solid. In the column, equilibrium can be only obtained layer by layer, interaction with air is low, and the solid is in excess. Big lysimeters in the field get natural precipitation and vegetation, and keep soil physical parameters (pores etc.), but getting a soil profile after the experiment is difficult.

From this, it was decided to study the formation of percolation water from arable soil layers in model columns in the dark. The experiment was rather abstract to confine retardation - mobilization effects to soil microbial life, neglecting horizontal flow, consumption by higher plants, and minimizing preferential flow effect through macropores. Addition of fertilizer solution to these soil columns and a subsequent long rainy period simulate worst case conditions for vertical transport of solutes down to deeper layers, in order to point out possible effects.

Chernozem soil samples from the most fertile areas of the east of Austria have been selected for this experiment, because they are known to develop rich microbial life, and they have high water retention capacities coupled with low water flow, thus enabling numerous transformation reactions to take place.

Details of the water regime during the experiments as well as of the determination of the effective pore volumes passing $50 \mathrm{~cm}^{3} \mathrm{KCl}$-solution, have been given by [10]. Effects concerning the added nutrients $\mathrm{P}$ and $\mathrm{K}$, as well as added trace elements As, B, Mo, Se and $\mathrm{V}$, and non-added main and trace elements, have been treated in detail in $[8,9]$.

\section{Experimental}

A haplic chernozem, calcic chernozem, and gleyic chernozem sample was taken at depth 1-10 cm, 10-20 cm and 20-30 cm, from topsoils at Sierndorf/March, at the eastern border of Lower Austria. After air drying, the samples were packed into 4 columns, each like the profile found in the field, to yield cylinders of $30 \mathrm{~cm}$ length, $12 \mathrm{~cm}$ diameter, and about $5 \mathrm{~kg}$ of dry mass. The soils were characterized by aqua regia and water extracts, soil 
$\mathrm{pH}$, clay size and carbonate contents (Table 1). In a pre-run, the effective pore volume of each column was determined experimentally by fitting the peak of penetrating chloride, applied as $\mathrm{KCl}$ solution.

Some characteristics of the soils investigated

\begin{tabular}{|c|c|c|c|c|}
\hline & & Haplic chernozem & Gleyic chernozem & Calcic chernozem \\
\hline Carbonate & $0-10 \mathrm{~cm}$ & 0 & $0.9 \%$ & $1.3 \%$ \\
\hline & $10-20 \mathrm{~cm}$ & 0 & $1.1 \%$ & $1.1 \%$ \\
\hline & $20-30 \mathrm{~cm}$ & 0 & $0.7 \%$ & $1.2 \%$ \\
\hline Humics & $0-10 \mathrm{~cm}$ & $0.9 \%$ & $2.5 \%$ & $3.6 \%$ \\
\hline & $10-20 \mathrm{~cm}$ & $0.9 \%$ & $2.5 \%$ & $3.4 \%$ \\
\hline & $20-30 \mathrm{~cm}$ & $1.0 \%$ & $1.9 \%$ & $3.4 \%$ \\
\hline Clay size & $0-10 \mathrm{~cm}$ & $7 \%$ & $13 \%$ & $13 \%$ \\
\hline & $10-20 \mathrm{~cm}$ & $7 \%$ & $14 \%$ & $13 \%$ \\
\hline & $20-30 \mathrm{~cm}$ & $7 \%$ & $15 \%$ & 22.3 \\
\hline Cation & $0-10 \mathrm{~cm}$ & 1.8 & 20.4 & 21.4 \\
\hline exchange & $10-20 \mathrm{~cm}$ & 2.3 & 20.2 & 22.3 \\
\hline capacity & $20-30 \mathrm{~cm}$ & 2.7 & 22.4 & 7.15 \\
\hline pH $\left(\right.$ CaCl $\left._{2}\right)$ & $0-10 \mathrm{~cm}$ & 4.2 & 7.0 & 7.2 \\
\hline & $10-20 \mathrm{~cm}$ & 4.25 & 7.05 & 7.2 \\
\hline & $20-30 \mathrm{~cm}$ & 4.25 & 7.35 & \\
\hline
\end{tabular}

Remark: pH given in 0.05 units, cation exchange capacity is given in cmolequ./kg, determined with $\mathrm{BaCl}_{2}$

The addition of mineral fertilizer was simulated by adding $50 \mathrm{~cm}^{3}$ of a $\mathrm{K} / \mathrm{Ca} / \mathrm{Mg} / \mathrm{NH}_{4}$ $/ / \mathrm{NO}_{3} / \mathrm{PO}_{4} / \mathrm{SO}_{4}$ - solution containing a cocktail of presumably anionic trace elements, ie $\mathrm{B}$, As, Se, Mo, and V. As the matrix for the trace elements, an inorganic N-P-K fertilizer was selected, with an application rate of $160 \mathrm{~kg} \mathrm{~N} / \mathrm{ha}$ as $\mathrm{NH}_{4} \mathrm{NO}_{3}, 320 \mathrm{~kg} \mathrm{P}_{2} \mathrm{O}_{5} / \mathrm{ha}$ as $\mathrm{Ca}\left(\mathrm{H}_{2} \mathrm{PO}_{4}\right)_{2} \cdot \mathrm{H}_{2} \mathrm{O}$, and $200 \mathrm{~kg} \mathrm{~K} 2 \mathrm{O} / \mathrm{ha}$ (from this $20 \%$ given as $\mathrm{K}_{2} \mathrm{SO}_{4}$ and $80 \%$ as $\mathrm{KCl}$, in order to avoid precipitation of gypsum). The trace elements were added in concentrations more than 100-fold above detection limit in the eluate solution, ie $50 \mathrm{mg} / \mathrm{dm}^{3} \mathrm{~B}$ and $\mathrm{V}$ each, $20 \mathrm{mg} / \mathrm{dm}^{3} \mathrm{Mo}$, and $10 \mathrm{mg} / \mathrm{dm}^{3}$ As and Se each, within $50 \mathrm{~cm}^{3}$ of loading solution. This means in absolute terms per column: $2.5 \mathrm{mg} \mathrm{B}$ and $\mathrm{V}, 1 \mathrm{mg} \mathrm{Mo}$, and $0.5 \mathrm{mg}$ As and Se, resp. $2 \mathrm{~g} / \mathrm{ha}, 0.8 \mathrm{~g} / \mathrm{ha}$ and $0.4 \mathrm{~g} / \mathrm{ha}$.

Every day except the weekends, 3 times $50 \mathrm{~cm}^{3}$ distilled water was added slowly via a pipette, to simulate natural rainfall, with intermediate periods of aeration. One addition matched about $1 / 10$ of effective pore volume. Eluates from pure gravity were taken from the bottom of the columns. About 4-5 effective pore volumes were collected. After collection of 40 fractions in 2 months, the columns were left dry for 6 weeks, and rewetted again with up to 6 portions of $150 \mathrm{~cm}^{3}$, in order to estimate the effect of drying and aeration.

The eluates were weighed, $\mathrm{pH}$ determined, and $\mathrm{HNO}_{3}$ suprapure added for stabilization. Most of the analytical data $(\mathrm{Al} / \mathrm{As} / \mathrm{B} / \mathrm{Be} / \mathrm{Ca} / \mathrm{Cd} / \mathrm{Co} / \mathrm{Cr} / \mathrm{Cu} / \mathrm{Fe} / \mathrm{K} / \mathrm{Li} /$ $\mathrm{Mg} / \mathrm{Mn} / \mathrm{Mo} / \mathrm{Ni} / \mathrm{Na} / \mathrm{P} / \mathrm{Pb} / \mathrm{S} / \mathrm{Sr} / \mathrm{V} / \mathrm{Zn}$ ) were obtained from ICP-OES multi-element determination from undiluted and 1+4 diluted samples, to serve as controls. Some samples at 1 effective pore volume had to be diluted $1+9$. The sensitivity for arsenic was too low, and therefore hydride-AAS had to be applied. For the determination of total selenium in the eluates, an aliquot was dried after addition of $\mathrm{KMnO}_{4}$-solution, ashed with $\mathrm{Mg}$-nitrate at $560^{\circ}$, and the ash dissolved in $1+1 \mathrm{HCl}$. Without this pretreatment, measured Se was 
negligible. $\mathrm{Be}, \mathrm{Cd}, \mathrm{Cr}$, and $\mathrm{Pb}$ were often below detection limit. Zinc desorbed from the vessels and gave significantly higher results after storage of about 3 months. The soil columns were kept in a dark room in the cellar, at about constant temperature $\left(21-24^{\circ}\right.$ and variable humidity (55-90\%). Evaporation was fairly constant and about 10\% [10].

\section{Results}

\section{Column eluates versus water extract}

The common water extract, performed with $5 \mathrm{~g}$ of solid sample shaken for 2 hours with $50 \mathrm{~cm}^{3}$ dist. $\mathrm{H}_{2} \mathrm{O}$, could not predict the release from the columns obtained during the long term experiment. Elution from the columns was much higher for $\mathrm{Fe}$ and $\mathrm{Mn}$, but also for $\mathrm{Sr}$ and $\mathrm{Ba}$. An increase for the non-added mobile cations $\mathrm{Li}-\mathrm{Na}-\mathrm{Mg}$ was expected to follow the order of the Cation Exchange Capacity (CEC), determined with $\mathrm{BaCl}_{2}$, but this was actually not quite the case. $\mathrm{Al}, \mathrm{Cu}$, and $\mathrm{Zn}$, however, were retained on the column more than predicted from the water extract. $\mathrm{Ca}$ and $\mathrm{S}$ release from the columns was more than calculated from batch release, even when the added amounts are taken into consideration (Table 2).

Within Table 2, an overview about the budget of selected nutrients is shown. Adsorption and migration reactions of added As, $\mathrm{S}$, and Se, as well as added $\mathrm{K}, \mathrm{P}, \mathrm{Mo}$, and $\mathrm{V}$ have been treated in previous papers $[8,9]$. As the input, the solubilities determined in the water extract, times the collected volume of the eluate, plus added amounts, are defined. The output is the sum of the material released to the eluates. Whereas boron was largely recovered again (the time was too short to obtain complete washout from the Haplic and Calcic chernozems), $\mathrm{P}$ and $\mathrm{K}$ were completely retained, and much more sulfur liberated.

Table 2

Budgets for added nutrients

\begin{tabular}{|c|c|c|c|c|c|c|c|}
\hline Ion & & $\begin{array}{c}\text { Water extract } \\
{\left[\mathbf{m g} / \mathbf{d m}^{\mathbf{3}}\right]}\end{array}$ & $\begin{array}{c}\text { Average pore } \\
\text { volumes for 40 } \\
\text { fractions }\end{array}$ & $\begin{array}{c}\text { Calculated load } \\
\text { from water } \\
\text { extract } \\
{[\mathbf{m g}]}\end{array}$ & $\begin{array}{c}\text { Added for } \\
\text { fertilization } \\
{[\mathbf{m g}]}\end{array}$ & $\begin{array}{c}\text { Load from } \\
\text { column in 40 } \\
\text { fractions } \\
{[\mathbf{m g}]}\end{array}$ & $\begin{array}{c}{[\%} \\
\text { eluted] }\end{array}$ \\
\hline B & $\mathrm{P}$ & 0.0505 & 5.12 & 0.258 & 2.5 & 1.75 & $63 \%$ \\
\hline & $\mathrm{F}$ & 0.0543 & 4.79 & 0.260 & 2.5 & 2.76 & $100 \%$ \\
\hline & $\mathrm{T}$ & 0.0390 & 4.52 & 0.176 & 2.5 & 0.95 & $36 \%$ \\
\hline K & $\mathrm{P}$ & 5.60 & 5.12 & 28.7 & 4150 & 113 & $2.7 \%$ \\
\hline & $\mathrm{F}$ & 2.18 & 4.79 & 10.4 & 4150 & 4.5 & $0.11 \%$ \\
\hline & $\mathrm{T}$ & 9.40 & 4.52 & 42.5 & 4150 & 113 & $2.7 \%$ \\
\hline P & $\mathrm{P}$ & 2.02 & 5.12 & 10.3 & 175 & 31.3 & $0.17 \%$ \\
\hline & $\mathrm{F}$ & 0.14 & 4.79 & 0.67 & 175 & 0.11 & $<0.1 \%$ \\
\hline & $\mathrm{T}$ & 0.88 & 4.52 & 3.98 & 175 & 1.26 & $0.7 \%$ \\
\hline S & $\mathrm{P}$ & 0.50 & 5.12 & 2.56 & 17 & 46 & $235 \%$ \\
\hline & $\mathrm{F}$ & 0.76 & 4.79 & 3.64 & 17 & 59 & $286 \%$ \\
\hline & $\mathrm{T}$ & 1.09 & 4.52 & 4.93 & 17 & 63 & $287 \%$ \\
\hline
\end{tabular}

$\mathrm{F}=$ Gleyic chernozem, $\mathrm{P}=$ Haplic chernozem, $\mathrm{T}=$ Calcic chernozem

\section{Changes of leachable main ion concentration during 2 months of intense rain}

The experimental setup simulated a long rainy period of 8 weeks. Addition of the NPK fertilizer solution resulted in the release of several non-added cations, like $\mathrm{Na}, \mathrm{Li}, \mathrm{Ca}, \mathrm{Mg}$, 
$\mathrm{Sr}, \mathrm{Ba}$, and $\mathrm{H}$, as well as sulfate, which peaked at about one pore volume. After this, all concentrations of non-added ions reached a steady state again (at 4.4-5.1 pore volumes), which was lower than from the conditions of the start (at 0-0.35 pore volumes), probably because of the exhaustion of the soluble phases, except for $\mathrm{Ca}$ from the Calcic and $\mathrm{Al}$ from the Haplic chernozem columns (see Tables 4-6 and Figs 1-3). Just the Na decline could be fitted with a hyperbolic function (Langmuir desorption). After the slight acidification at about one pore volume, the $\mathrm{pH}$ slightly and steadily increased.

\section{Effect of a dry period}

After a period of about 6 weeks after the end of periodical addition of water on top of the columns, they were rewetted again with portions of $150 \mathrm{~cm}^{3}$ each, from the top. After 2-3 additions, the original amounts of eluates were collected. The concentrations found in the eluates are given in Tables 3-5 as the means of the 4 columns run in parallel for each soil type, together with mean concentrations met in the eluates obtained before and after the fertilization pulse.

Table 3

Mean of eluate concentrations before and after the ion-exchange peak, and fractions after re-wetting, for the Haplic chernozem

\begin{tabular}{|c|c|c|c|c|c|c|c|c|}
\hline & & Before & After & \multicolumn{5}{|c|}{ Fractions after drying } \\
\hline & & \multicolumn{2}{|c|}{ the ion exchange peak } & & & & & \\
\hline & & \multicolumn{2}{|c|}{ Eluted pore volumes $\rightarrow$} & 0 & 0.109 & 0.232 & 0.348 & 0.455 \\
\hline $\mathbf{C a}$ & {$\left[\mathrm{mg} / \mathrm{dm}^{3}\right]$} & 50.5 & $12.8 \pm 1.6$ & 15.0 & 19.9 & 24.8 & 26.4 & 26.1 \\
\hline $\mathbf{F e}$ & {$\left[\mathrm{mg} / \mathrm{dm}^{3}\right]$} & 62.5 & $12.6 \pm 5.3$ & 7.16 & 10.29 & 9.38 & 17.49 & 13.23 \\
\hline $\mathbf{K}$ & {$\left[\mathrm{mg} / \mathrm{dm}^{3}\right]$} & 27.2 & $15.4 \pm 3.6$ & 26.1 & 26.7 & 40.0 & 45.1 & 40.8 \\
\hline Mg & {$\left[\mathrm{mg} / \mathrm{dm}^{3}\right]$} & 6.3 & $1.6 \pm 0.2$ & 1.98 & 2.69 & 3.21 & 4.06 & 3.81 \\
\hline Mn & {$\left[\mathrm{mg} / \mathrm{dm}^{3}\right]$} & 22.8 & $5.12 \pm 1.38$ & 5.80 & 7.99 & 11.45 & 12.73 & 13.28 \\
\hline $\mathrm{Na}$ & {$\left[\mathrm{mg} / \mathrm{dm}^{3}\right]$} & 0.70 & $0.10 \pm 0.02$ & 0.14 & 0.14 & 0.43 & 0.48 & 0.24 \\
\hline $\mathbf{P}$ & {$\left[\mathrm{mg} / \mathrm{dm}^{3}\right]$} & 1.93 & $8.10 \pm 2.58$ & 1.21 & 1.54 & 0.92 & 1.41 & 1.15 \\
\hline $\mathbf{S}$ & {$\left[\mathrm{mg} / \mathrm{dm}^{3}\right]$} & 1.32 & $0.35 \pm 0.05$ & 4.17 & 3.50 & 4.86 & 4.63 & 3.03 \\
\hline $\mathbf{S r}$ & {$\left[\mathrm{mg} / \mathrm{dm}^{3}\right]$} & 0.206 & $0.050 \pm 0.007$ & 0.055 & 0.070 & 0.103 & 0.113 & 0.114 \\
\hline \multicolumn{3}{|c|}{ Trace elements } & & & & & & \\
\hline Al & {$\left[\mathrm{mg} / \mathrm{dm}^{3}\right]$} & 0.276 & 1.033 & 0.205 & 0.263 & 0.166 & 0.148 & 0.272 \\
\hline As & {$\left[\mathrm{mg} / \mathrm{dm}^{3}\right]$} & 0.019 & Added & n.d. & 0.0063 & 0.0042 & 0.0048 & 0.0075 \\
\hline B & {$\left[\mathrm{mg} / \mathrm{dm}^{3}\right]$} & 0.089 & Added & 0.162 & 0.133 & 0.216 & 0.191 & 0.183 \\
\hline $\mathbf{B a}$ & {$\left[\mathrm{mg} / \mathrm{dm}^{3}\right]$} & 0.103 & 0.025 & 0.028 & 0.034 & 0.049 & 0.062 & 0.060 \\
\hline $\mathbf{B e}$ & {$\left[\mathrm{mg} / \mathrm{dm}^{3}\right]$} & 0.0003 & 0.00008 & 0.00006 & $<0.00004$ & $<0.00004$ & $<0.00004$ & $<0.00004$ \\
\hline Cd & {$\left[\mathrm{mg} / \mathrm{dm}^{3}\right]$} & $<0.0004$ & $<0.0004$ & $<0.0004$ & 0.0059 & 0.0058 & 0.0020 & 0.0051 \\
\hline Co & {$\left[\mathrm{mg} / \mathrm{dm}^{3}\right]$} & 0.133 & 0.049 & 0.026 & 0.049 & 0.051 & 0.065 & 0.059 \\
\hline $\mathrm{Cr}$ & {$\left[\mathrm{mg} / \mathrm{dm}^{3}\right]$} & 0.0017 & 0.0027 & 0.007 & 0.0028 & 0.0022 & $<0.0005$ & $<0.0005$ \\
\hline $\mathbf{C u}$ & {$\left[\mathrm{mg} / \mathrm{dm}^{3}\right]$} & 0.012 & 0.007 & 0.0124 & 0.0081 & 0.0086 & 0.0083 & 0.0059 \\
\hline $\mathbf{L i}$ & {$\left[\mathrm{mg} / \mathrm{dm}^{3}\right]$} & 0.0038 & 0.0026 & 0.004 & 0.004 & 0.006 & 0.005 & 0.006 \\
\hline Mo & {$\left[\mathrm{mg} / \mathrm{dm}^{3}\right]$} & 0.0012 & Added & 0.0022 & 0.0040 & 0.0035 & 0.0057 & 0.0033 \\
\hline $\mathbf{N i}$ & {$\left[\mathrm{mg} / \mathrm{dm}^{3}\right]$} & 0.134 & 0.052 & 0.022 & 0.049 & 0.038 & 0.038 & 0.036 \\
\hline $\mathbf{P b}$ & {$\left[\mathrm{mg} / \mathrm{dm}^{3}\right]$} & 0.0078 & 0.005 & 0.004 & 0.009 & 0.009 & $<0.003$ & $<0.003$ \\
\hline $\mathbf{V}$ & {$\left[\mathrm{mg} / \mathrm{dm}^{3}\right]$} & $<0.0007$ & Added & 0.0051 & 0.0015 & 0.0008 & 0.0010 & 0.0016 \\
\hline Zn & {$\left[\mathrm{mg} / \mathrm{dm}^{3}\right]$} & 0.038 & 0.008 & 0.013 & 0.017 & 0.015 & 0.008 & 0.009 \\
\hline
\end{tabular}

Compared with the steady state reached before the drying period, more $\mathrm{K}$ and $\mathrm{S}$ were generally released. S rather shows a "snowball effect", its peak was smaller than from the 
chloride which had been chosen to determine the actual pore volumes. From the Gleyic and the Calcic chernozem sample columns, a decrease in Fe and Mn mobility paralleled an increase of P. In the Haplic chernozem, from which appreciable washout of P had already taken place, drying led to $\mathrm{P}$ fixation. Other ions investigated reached about the same level as before the drying period.

Table 4

Mean of eluate concentrations before and after the ion-exchange peak, and fractions after re-wetting, for the Gleyic chernozem

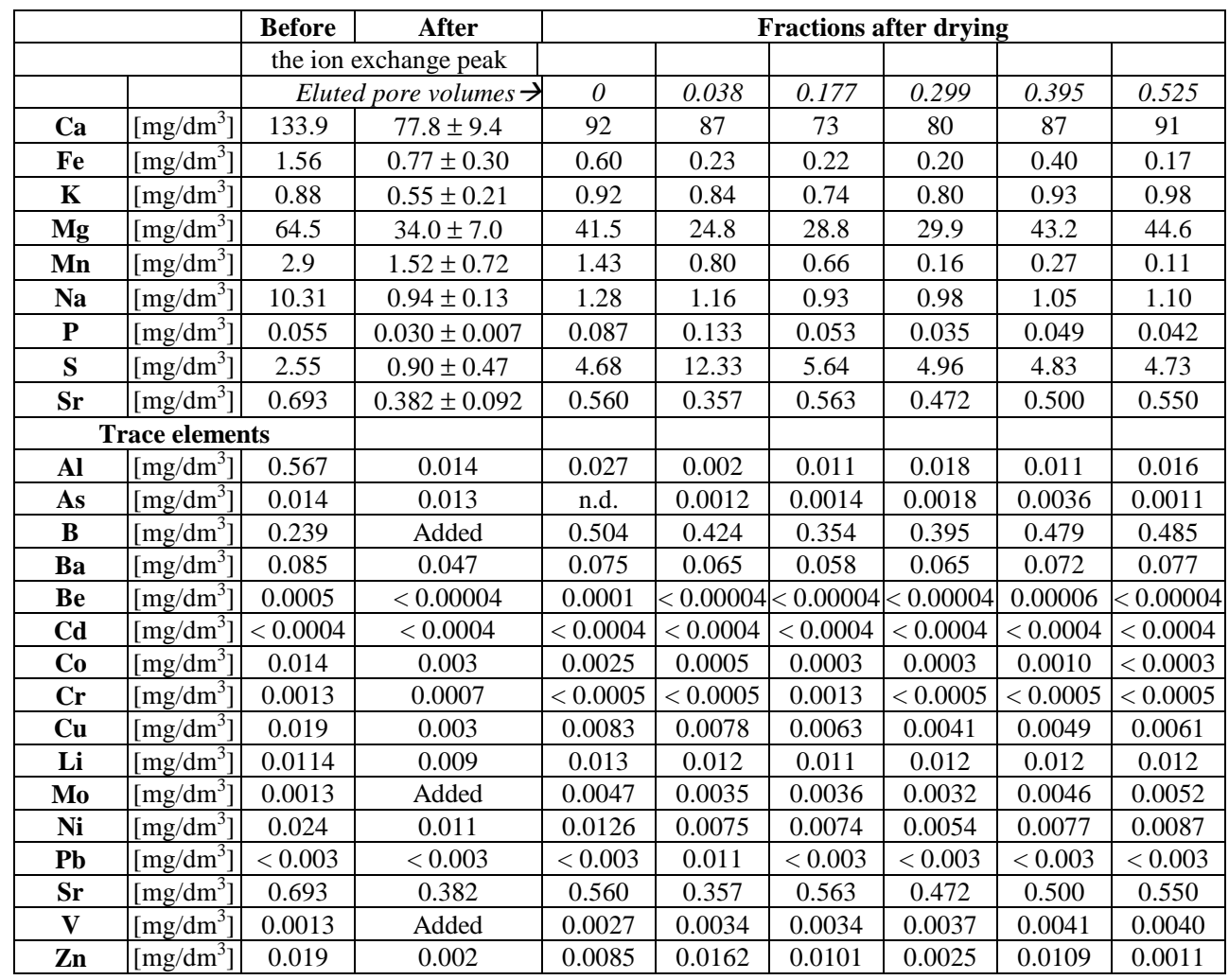

Table 5

Mean of eluate concentrations before and after the ion-exchange peak, and fractions after re-wetting, for the Calcic chernozem

\begin{tabular}{|c|c|c|c|c|c|c|c|c|c|}
\hline \multicolumn{2}{|c|}{} & Before & After & \multicolumn{7}{c|}{ Fractions after drying } \\
\hline \multicolumn{2}{|c|}{} & \multicolumn{2}{|c|}{ the ion exchange peak } & & & & & & \\
\hline & & Eluted pore volumes $\rightarrow$ & 0 & 0.036 & 0.131 & 0.238 & 0.338 & 0.457 \\
\hline $\mathbf{C a}$ & {$\left[\mathrm{mg} / \mathrm{dm}^{3}\right]$} & 174 & $156 \pm 13$ & 128 & 214 & 207 & 189 & 170 & 194 \\
\hline $\mathbf{F e}$ & {$\left[\mathrm{mg} / \mathrm{dm}^{3}\right]$} & 10.3 & $3.03 \pm 1.14$ & 0.79 & 0.29 & 0.14 & 0.07 & 0.09 & 0.15 \\
\hline $\mathbf{K}$ & {$\left[\mathrm{mg} / \mathrm{dm}^{3}\right]$} & 39.6 & $22.1 \pm 4.8$ & 29.4 & 42.1 & 40.8 & 37.9 & 35.3 & 37.6 \\
\hline $\mathbf{M g}$ & {$\left[\mathrm{mg} / \mathrm{dm}^{3}\right]$} & 28.5 & $12.4 \pm 1.8$ & 13.02 & 15.49 & 14.37 & 13.21 & 15.76 & 15.74 \\
\hline $\mathbf{M n}$ & {$\left[\mathrm{mg} / \mathrm{dm}^{3}\right]$} & 7.3 & $4.48 \pm 0.18$ & 1.92 & 2.32 & 1.60 & 1.57 & 1.98 & 2.32 \\
\hline $\mathbf{N a}$ & {$\left[\mathrm{mg} / \mathrm{dm}^{3}\right]$} & 5.50 & $0.76 \pm 0.06$ & 0.65 & 1.18 & 1.05 & 0.95 & 1.03 & 0.99 \\
\hline
\end{tabular}




\begin{tabular}{|c|c|c|c|c|c|c|c|c|c|}
\hline $\mathbf{P}$ & {$\left[\mathrm{mg} / \mathrm{dm}^{3}\right]$} & 0.259 & $0.224 \pm 0.031$ & 0.403 & 0.386 & 0.205 & 0.136 & 0.165 & 0.133 \\
\hline $\mathbf{S}$ & {$\left[\mathrm{mg} / \mathrm{dm}^{3}\right]$} & 2.47 & $0.88 \pm 0.30$ & 6.35 & 68.5 & 51.02 & 30.16 & 20.09 & 18.97 \\
\hline $\mathbf{S r}$ & {$\left[\mathrm{mg} / \mathrm{dm}^{3}\right]$} & 0.588 & $0.35 \pm 0.02$ & 0.39 & 0.51 & 0.48 & 0.44 & 0.40 & 0.47 \\
\hline \multicolumn{3}{|c|}{$\mathbf{T r a c e ~ e l e m e n t s ~}$} & & & & & & & \\
\hline $\mathbf{A l}$ & {$\left[\mathrm{mg} / \mathrm{dm}^{3}\right]$} & 0.049 & 0.035 & 0.298 & 0.031 & 0.021 & 0.010 & 0.006 & 0.024 \\
\hline $\mathbf{A s}$ & {$\left[\mathrm{mg} / \mathrm{dm}^{3}\right]$} & 0.017 & Added & n.d & 0.0024 & 0.0021 & n.d. & 0.0027 & n.d. \\
\hline $\mathbf{B}$ & {$\left[\mathrm{mg} / \mathrm{dm}^{3}\right]$} & 0.082 & Added & 0.27 & 0.39 & 0.33 & 0.34 & 0.47 & 0.44 \\
\hline $\mathbf{B a}$ & {$\left[\mathrm{mg} / \mathrm{dm}^{3}\right]$} & 0.139 & 0.090 & 0.14 & 0.19 & 0.18 & 0.19 & 0.20 & 0.22 \\
\hline $\mathbf{B e}$ & {$\left[\mathrm{mg} / \mathrm{dm}^{3}\right]$} & 0.0003 & $<0.00004$ & 0.00005 & $<0.0004$ & $<0.0004$ & $<0.0004$ & $<0.0004$ & $<0.0004$ \\
\hline $\mathbf{C d}$ & {$\left[\mathrm{mg} / \mathrm{dm}^{3}\right]$} & $<0.0004$ & $<0.0004$ & $<0.0004$ & $<0.0004$ & $<0.0004$ & $<0.0004$ & $<0.0004$ & $<0.0004$ \\
\hline $\mathbf{C o}$ & {$\left[\mathrm{mg} / \mathrm{dm}^{3}\right]$} & 0.005 & 0.005 & 0.0065 & 0.0024 & 0.0010 & 0.0010 & 0.0014 & 0.0026 \\
\hline $\mathbf{C r}$ & {$\left[\mathrm{mg} / \mathrm{dm}^{3}\right]$} & 0.0010 & $<0.0005$ & 0.0019 & $<0.0005$ & $<0.0005$ & $<0.0005$ & $<0.0005$ & $<0.0005$ \\
\hline $\mathbf{C u}$ & {$\left[\mathrm{mg} / \mathrm{dm}^{3}\right]$} & 0.025 & 0.016 & 0.107 & 0.025 & 0.019 & 0.018 & 0.020 & 0.020 \\
\hline $\mathbf{L i}$ & {$\left[\mathrm{mg} / \mathrm{dm}^{3}\right]$} & 0.0052 & 0.0028 & 0.006 & 0.009 & 0.008 & 0.007 & 0.007 & 0.008 \\
\hline $\mathbf{M o}$ & {$\left[\mathrm{mg} / \mathrm{dm}^{3}\right]$} & 0.00014 & Added & 0.007 & 0.002 & 0.002 & 0.002 & 0.004 & 0.009 \\
\hline $\mathbf{N i}$ & {$\left[\mathrm{mg} / \mathrm{dm}^{3}\right]$} & 0.023 & 0.015 & 0.032 & 0.012 & 0.010 & 0.007 & 0.009 & 0.013 \\
\hline $\mathbf{P b}$ & {$\left[\mathrm{mg} / \mathrm{dm}^{3}\right]$} & $<0.003$ & $<0.003$ & 0.008 & $<0.003$ & $<0.003$ & $<0.003$ & $<0.003$ & $<0.003$ \\
\hline $\mathbf{V}$ & {$\left[\mathrm{mg} / \mathrm{dm}^{3}\right]$} & $<0.0007$ & Added & 0.0034 & 0.0011 & 0.0020 & 0.0024 & 0.0021 & 0.0012 \\
\hline $\mathbf{Z n}$ & {$\left[\mathrm{mg} / \mathrm{dm}^{3}\right]$} & 0.016 & 0.003 & 0.167 & 0.0092 & 0.0085 & 0.0027 & 0.0023 & 0.0027 \\
\hline
\end{tabular}

\section{Precipitates in the eluates}

After 9 months of drying, the soil columns were dismantled und cut into 6 aliquots in order to enable investigations of the respective soil profiles. Compared with the original lengths of the columns of $30 \mathrm{~cm}$ of air-dried soil, the cores packed together to yield 24-27 cm. In the depicted figures, however, the length axis is taken as the original one. The paper filter, which was inserted at the soil bottoms to prevent wash-out of fine particles, was not visible any more, except for the Haplic Chernozem. The quartz sand cover on top, which should lead to a homogenous distribution of the applied eluents on the entire cross-section, of the columns could be removed easily. The cores were surprisingly compact. Veins of suspended quartz from the top layer were visible from outside, but they were present just on the mantle.

Table 6

Composition of the precipitates at the column outlets, given in $\%$ of silicate-free solid

\begin{tabular}{|c|c|c|c|c|c|c|c|c|c|c|}
\hline & \multicolumn{4}{|c|}{ Haplic chernozem } & \multicolumn{3}{c|}{ Gleyic chernozem } & \multicolumn{2}{c|}{ Calcic ch. } \\
\hline \% & P1 & P2 & P3 & P4 & F1 & F2 & F3 & F4 & T1 & T2 \\
\hline $\mathbf{A l}(\mathbf{O H})_{3}$ & 5.3 & 4.2 & 8.0 & 2.9 & 4.4 & 3.0 & 17.4 & 3.6 & 7.1 & 2.6 \\
\hline $\mathbf{F e O O H}$ & 67.7 & 69.9 & 63.4 & 65.3 & 7.1 & 6.5 & 9.2 & 6.2 & 10.9 & 11.4 \\
\hline $\mathbf{M n O O H}$ & 3.5 & 3.5 & 4.3 & 4.2 & 2.6 & 2.4 & 1.0 & 2.0 & 3.4 & 3.7 \\
\hline $\mathbf{C a C O}_{\mathbf{3}}$ & 6.5 & 5.4 & 7.0 & 7.4 & 80.5 & 83.3 & 64.9 & 83.4 & 75.6 & 80.3 \\
\hline $\mathbf{M g C O}_{\mathbf{3}}$ & 3.0 & 1.4 & 2.2 & 1.1 & 5.3 & 4.7 & 7.4 & 4.8 & 2.9 & 2.1 \\
\hline $\mathbf{P}_{\mathbf{2}} \mathbf{O}_{\mathbf{5}}$ & 14.1 & 15.6 & 15.1 & 9.0 & $<$ & $<$ & $<$ & $<$ & $<$ & $<$ \\
\hline $\mathbf{F e}+\mathbf{M n}+\mathbf{A l}$ & 76.5 & 77.6 & 75.7 & 72.4 & 14.1 & 11.9 & 27.6 & 11.8 & 21.4 & 17.7 \\
\hline $\mathbf{C a} \mathbf{M g}$ & 9.5 & 6.8 & 9.2 & 8.5 & 85.8 & 88 & 72.3 & 88.2 & 78.5 & 82.4 \\
\hline
\end{tabular}

P1.. T2: column labels

In the bottom plates and the outlets of the funnels, which carried the soil columns, a brown precipitate occurred. The funnels were separated from remaining soil material as well as possible, and the brown residues were dissolved with hydrochloric acid on the boiling water bath, made up to $250 \mathrm{~cm}^{3}$, and submitted to multi-element analysis. In case, 
$\mathrm{Fe}$ is calculated as $\mathrm{FeOOH}$, manganese as $\mathrm{MnOOH}$, aluminum as $\mathrm{Al}(\mathrm{OH})_{3}$, magnesium as $\mathrm{MgCO}_{3}$, calcium as $\mathrm{CaCO}_{3}$ and phosphorus as $\mathrm{P}_{2} \mathrm{O}_{5}$ (to allow addition of the weights together with $\mathrm{FeOOH}$ und $\mathrm{MnOOH}$ ), and take the sum of these 6 main elements as $100 \%$ (silicon is lacking; the weight of the traces is negligible), this leads to the results of the composition of the precipitates given in the subsequent Table 6 .

In the eluates of the non-contaminated chernozem soils treated in this study, significantly more arsenic was found in the eluates than expected from the mean of the groundwater monitoring program, in spite of the fact that half of the mobilized arsenic was scavenged in the ochre at the column outlet. In wells, ochre formation thus seems to be a major sink of arsenic.

The precipitate formed on contact with air after exiting the soil column was identified as a Fe/Mn-hydroxide carrying appreciable amounts of phosphate for the (acid) Haplic Chernozem, and a Ca carbonate for the (slightly alkaline) Calcic and Gleyic Chernozems. Co-precipitated $\mathrm{Al}$ was variable and seemed to be accidental.

These precipitation products can be explained by oxidation of soluble divalent Fe and decline of $\mathrm{CO}_{2}$ partial pressure on the air. Some of the eluted trace elements are caught in these precipitates, others are not, which could lead to artefacts in the interpretation of the elution curves. For alkali and alkaline earth elements (except $\mathrm{Ca}$ ), the precipitated quantity in the run-off is, however, marginal. Figure 4 shows the scavenging effect of these precipitates at the column outlet by depicting the proportion found in the eluate. At the average, scavenging took place in the order $\mathrm{Cr}>\mathrm{Al}>\mathrm{Pb}>\mathrm{P}>\mathrm{V}>\mathrm{Fe}>\mathrm{Be}>\mathrm{Zn}>\mathrm{As}>$ $\mathrm{Cu}>\mathrm{Ba}>\mathrm{Co}>\mathrm{Mn}>\mathrm{Ni}>\mathrm{Ca}>\mathrm{Li}>\mathrm{Mo}>\mathrm{Sr}>\mathrm{Mg}>\mathrm{K}>\mathrm{Se}>\mathrm{B}$ (Fig. 4). Thus, Cr, Al, $\mathrm{Pb}, \mathrm{P}$ $\mathrm{V}, \mathrm{Fe}$ and also $\mathrm{Zn}$ mainly precipitate, when well water is aerated again.

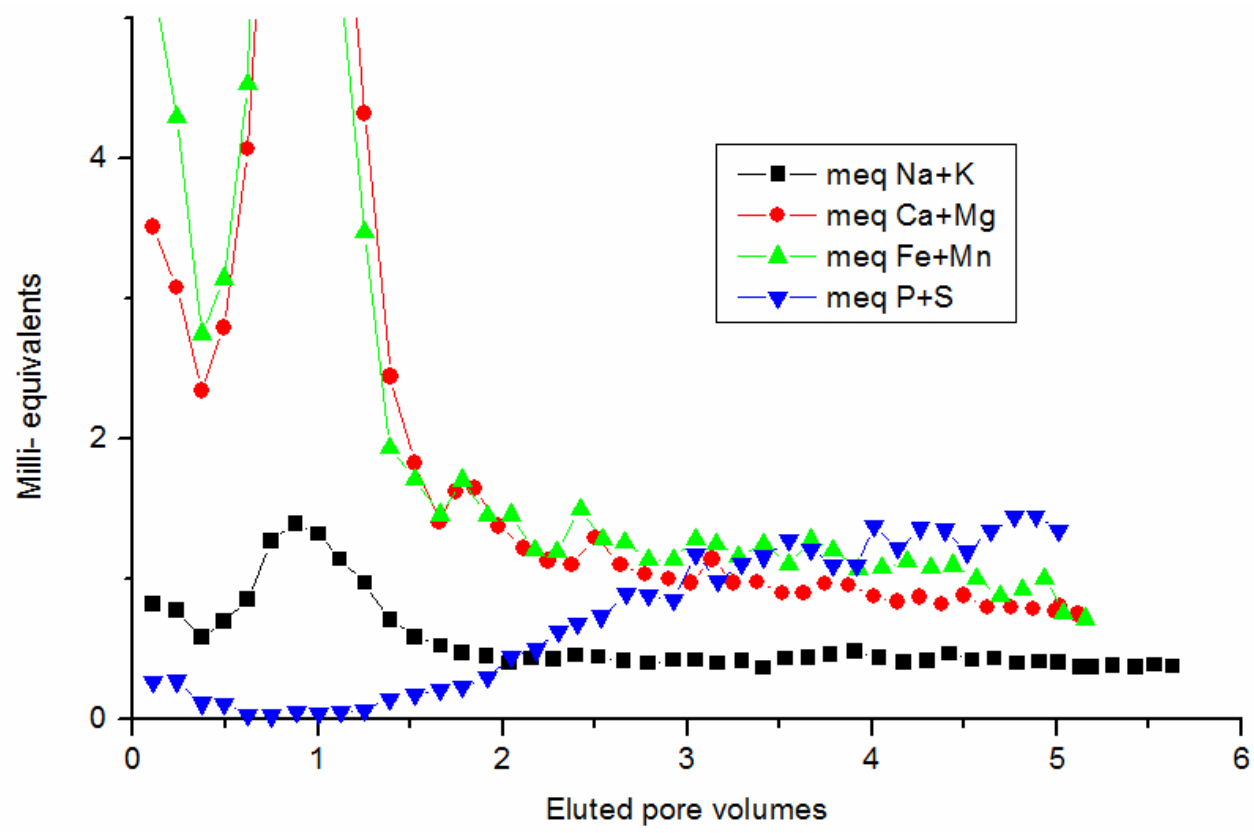

Fig. 1. Eluates of the Haplic Chernozem - main composition in milli-equivalents 


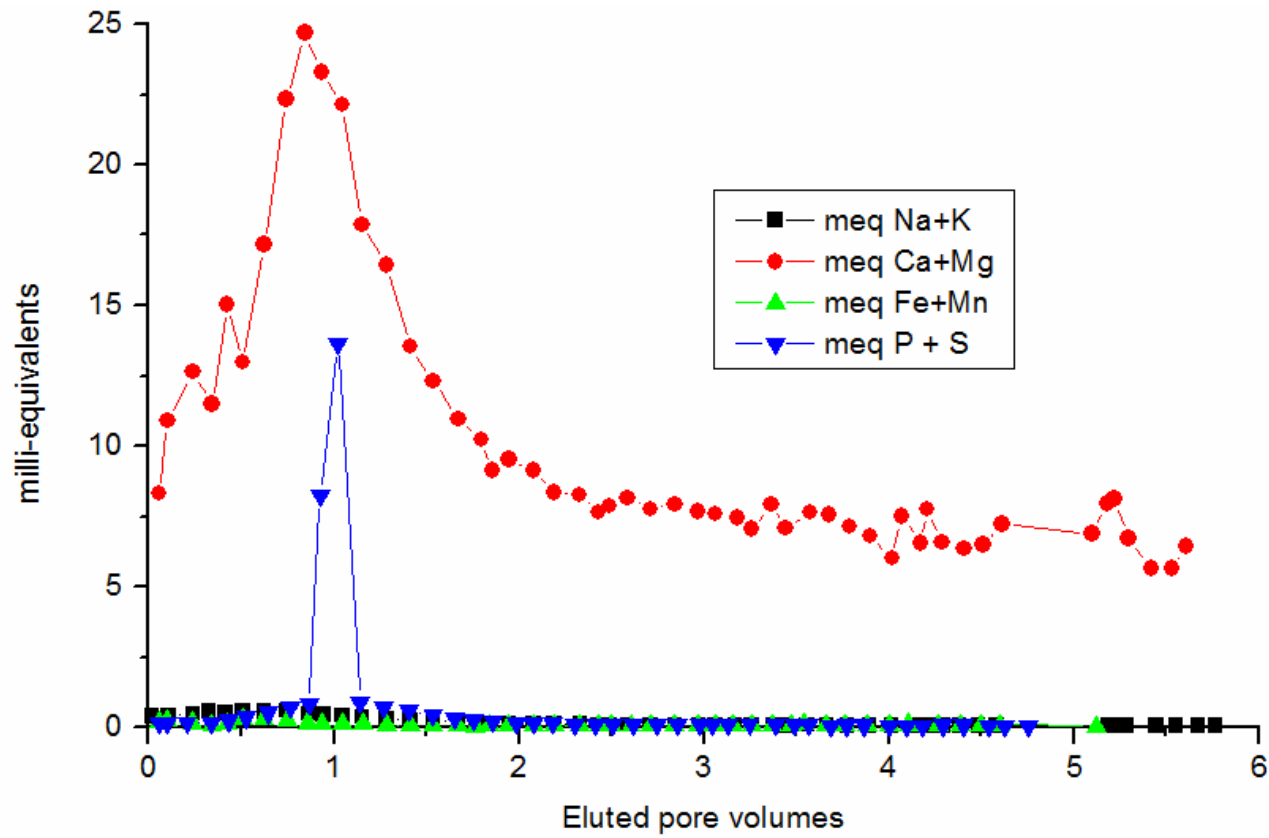

Fig. 2. Eluates of the Gleyic Chernozem - main composition in milli-equivalents

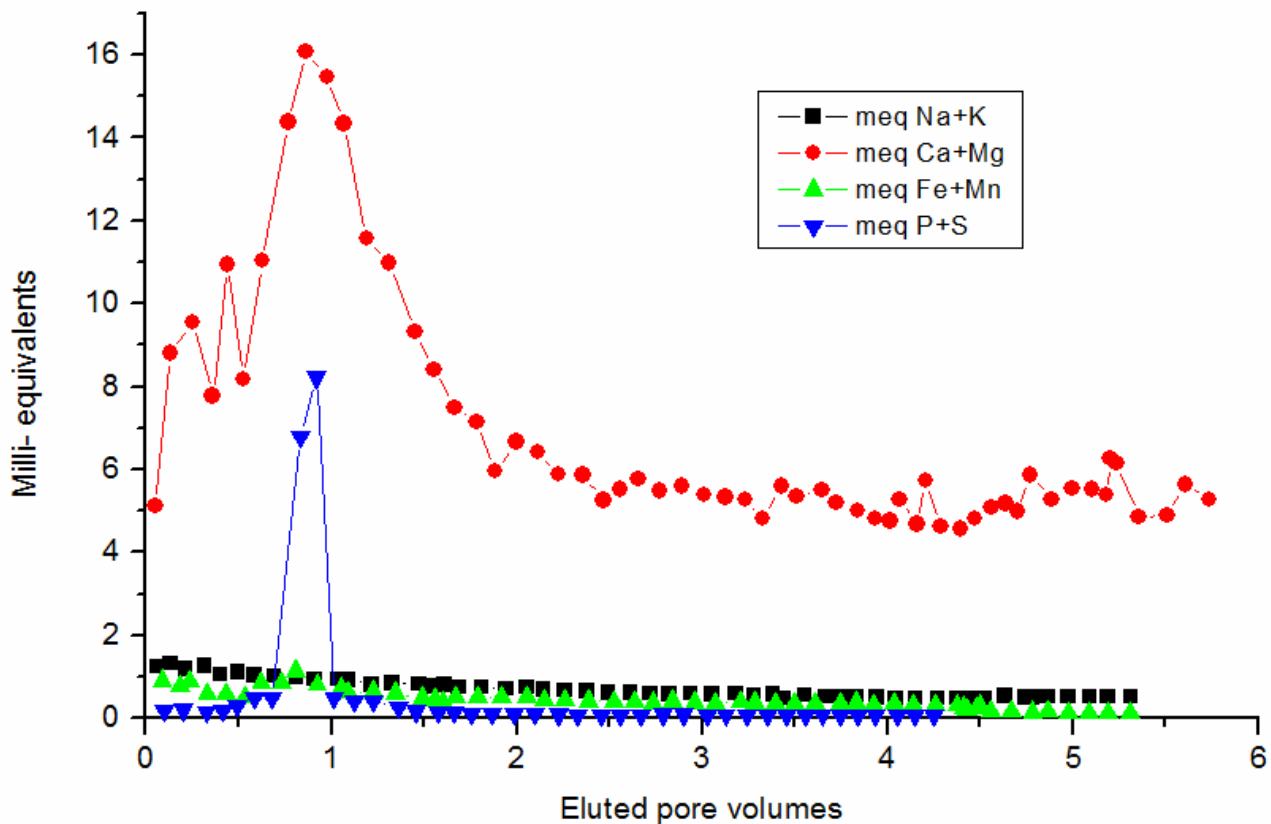

Fig. 3. Eluates of the Calcic Chernozem - main composition in milli-equivalents 
From the acid eluate of the Haplic chernozem, $\mathrm{P} / \mathrm{As} / \mathrm{Co} / \mathrm{Mn} / \mathrm{Ni}$ were significantly less depleted in this brown precipitate, than from the alkaline eluates of the Gleyic and Calcic chernozem samples.

Precipitations of $\mathrm{Fe} / \mathrm{Mn}$ compounds are known to occur in tubes of wells, as the ochering-effect, in case too much air penetrates down to the groundwater horizon [5]. This clogs the well, but obviously prevents contamination of the well water with a lot of ,heavy metals" (see above). Similarly, precipitation and deposition of $\mathrm{CaCO}_{3}$ at freshwater sources occur from shifts of the $\mathrm{CaCO}_{3}-\mathrm{CO}_{2}$ equilibrium. Soil gases may contain 10-100 times more $\mathrm{CO}_{2}$ than the common atmosphere, because it is steadily formed by respiration of plant roots and soil microbes [5].

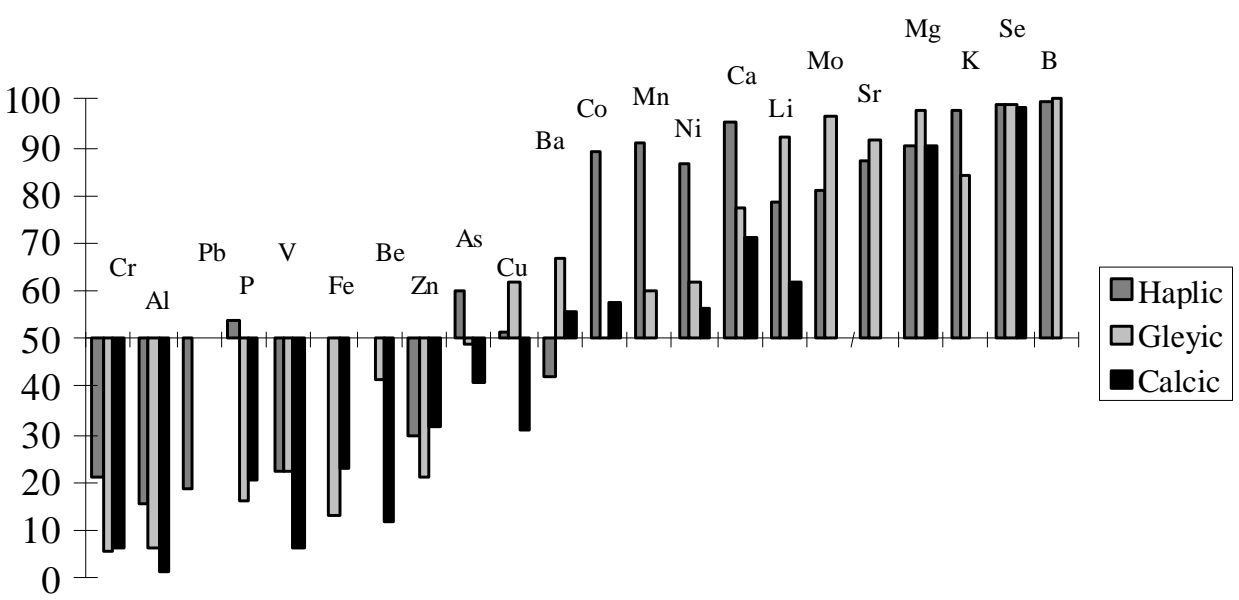

Fig. 4. Amounts released to the eluates versus amounts scavenged in the ochre 100 means: $100 \%$ pass into the eluate

\section{Conclusions}

In terms of water classification (cited in MATTHESS 1990), all obtained percolate waters have to be classified as $\mathrm{Ca}-\mathrm{Mg}-\mathrm{HCO}_{3}$ waters, before and after the fertilization process. The water hardness would be hard from the Gleyic and Calcic chernozem columns, and soft from the Haplic chernozem columns. The water leaving the Haplic chernozem may be termed as an ,iron-source“-water $\left(\mathrm{Fe}>10 \mathrm{mg} / \mathrm{dm}^{3}\right)$.

The formation of groundwater may be regarded to be a continuous process leading to constant composition of well water. But in detail, the situation is more complex. The composition of ground water formed below chernozem soils was found to be irreversibly influenced from fertilizing events by ion exchange. After a long rainy periods, a new steady state of percolate composition was reached, which was unpredictable from the simple water extract. After the drying period, a decrease of $\mathrm{Fe}$ and $\mathrm{Mn}$ in the eluates coupled with additional release of sulfur can be interpreted as an effect of aeration and degradation of organic substances. 
Of course, this composition of the water leached from the topsoil, might be modified when permeating into deeper layers. In the bottom plates and the outlets of the funnels, which carried the soil columns, a brown precipitate occurred, which is commonly termed as ochre formation. This was presumably mainly Fe-hydroxide for the Haplic, and $\mathrm{CaCO}_{3}$ for the Gleyic and Calcic chernozem samples, coinciding with the $\mathrm{pH}$ of the eluates. Major amounts of $\mathrm{Cr}, \mathrm{Al}, \mathrm{Pb}, \mathrm{P}, \mathrm{V}, \mathrm{Fe}$ and also $\mathrm{Zn}$ leaving the column, were found precipitated here, where re-aeration took place. From the acid eluate of the Haplic chernozem, $\mathrm{P} / \mathrm{As} / \mathrm{Co} / \mathrm{Mn} / \mathrm{Ni}$ were significantly less depleted in this brown precipitate, than from the alkaline eluates of the Gleyic and Calcic chernozem samples.

In terms of ground water contamination, these ochre formations protect well waters and thus the consumers from a lot of harmful trace elements, and exert an excellent filter. This is some kind of natural cleaning of the well water. $\mathrm{Mo}, \mathrm{Sr}, \mathrm{Mg}, \mathrm{K}, \mathrm{Se}$, and $\mathrm{B}$ were not significantly co-precipitated in these ochre layers.

\section{References}

[1] Schindler U, Meissner R, Müller L. Dynamik der Grundwasserneubildung auf pleistozänen Sandstandorten des Oder- und Elbe - Einzugsgebietes. Bericht der 7. Lysimetertagung: BAL Gumpenstein; 1997.

[2] Lintnerova O, Sucha V, Streško V. Mineralogy and Geochemistry of Acid Mine Fe-Precipitates from the Main Sloval Mining Regions. Geol. Carpathica. 1999;50(5):395-404.

[3] Pramberger F, Pavlik H. Grundwasser Monitoring in Österreich. Bericht der 7. Lysimetertagung: BAL Gumpenstein; 1997.

[4] Förstner U. Umweltschutztechnik. 5th Ed., Springer 1992.

[5] Matthess G. Grundwassererschließung, Lehrbuch der Hydrogeologie 4. Berlin Stuttgart: Gebrüder Borntraeger; 2000

[6] Sager M. Barrier effects of low- permeable clay type solids. experiments with model leachates containing $\mathrm{Cd}, \mathrm{Cu}, \mathrm{Ni}$, and $\mathrm{Pb}$ and organic acids. Geosystem Eng. 2001;4(1):1-12.

[7] Sager M. Assessment of Environmental Mobility by Selective Dissolution Methods and Column Studies. In: Application of Geosystem Engineering for Optimal Design of Underground Development and Environment in $21^{\text {st }}$ Century. Seoul: Korean Institute of Mineral and Energy Resources Engineers KIME; 2001.

[8] Sager M. Vertical mobility of selenium, arsenic and sulfur in model soil columns. Die Bodenkultur. 2002;53(2):83-103.

[9] Sager M. Effects of a fertilization pulse on migration of nutrient and trace elements in chernozem soil columns within a vegetation period. Die Bodenkultur. 2004;55(4):165-182.

[10] Schoissengeier M. Mobilität von Anionen in Bodensäulen. Master thesis at the University of Natural Resources and Applied Life Sciences, Vienna; 1999. 


\title{
FORMOWANIE WÓD GRUNTOWYCH PONIŻEJ WARSTWY GLEB CZARNOZIEMU - WPEYW NAWOŻENIA MINERALNEGO ORAZ OKRESÓW DESZCZOWYCH I SUCHYCH
}

\begin{abstract}
Abstrakt: Za pomocą doświadczeń kolumnowych zbadano wpływ nawożenia mineralnego na skład wody w głębszych warstwach gleby. W doświadczeniach wykorzystano próbki czarnoziemów zebranych na terenach wschodniej Austrii. Roztwór imitujący nawozy NPK wprowadzano na szczyt kolumny nasyconej wodą porcjami po $150 \mathrm{~cm}^{3}$ roztworu (co stanowiło około 0,1 objętości porów) codziennie, z wyjątkiem weekendów, przez 2 miesiące. Eluaty zebrano i poddano analizie metodami ICP i AAS. Po zastosowaniu porcji roztworu odpowiadającej jednej objętości porów, zarejestrowano w odcieku silny pik alkaliczny i siarczanowy, będący skutkiem wymiany jonowej z roztworem. Następnie większość stężeń w eluatach była stabilna, ale ich wartości były niższe niż wcześniej. Po okresie suszenia uwalnianie K, S, i P w 2 z 3 przypadków uległo zwiększeniu, podczas gdy uwalnianie Fe i Mn spadło. Zanim eluaty trafiły do pojemników, strącana ochra oczyszczała roztwór $\mathrm{Z}$ wielu substancji rozpuszczonych $(\mathrm{Cr}>\mathrm{Al}>\mathrm{Pb}>\mathrm{P}>\mathrm{V}>\mathrm{Fe})$, ale Mo-Sr-Mg-K-Se-B pozostały raczej niezmienione.
\end{abstract}

Słowa kluczowe: kolumny glebowe, migracja pionowa, tworzenie ochry, nawożenie, podpowierzchniowe wody gruntowe 